\title{
Analysis of Pharmaceutical Company Websites using Innovation Diffusion Theory and Technology Acceptance Model
}

\author{
Mochammad Haldi Widianto* \\ Informatics Departement, School of Computer Science , Bina Nusantara University, Jakarta, Indonesia, 11480
}

\author{
A R T I C L E IN F O \\ Article history: \\ Received: 07 December, 2020 \\ Accepted: 13 January, 2021 \\ Online: 22 January, 2021
}

Keywords:

Technology Acceptance Mode

Innovation Diffusion Theory

Pharmaceutical Companies

\begin{abstract}
A B S T R A C T
The progress of information using websites is developing fast, impacting various sectors, one of which is pharmaceutical companies. Pharmaceutical companies have roles in drug manufacturing, pharmaceutical distribution, and essential services for the community - the most important and challenging activity in the IT department. The researcher is responsible for one of the Bandung pharmaceutical companies. Researchers are trading IT service managers for drug manufacturing, drug distribution, and community service units that have been conducted online. The company has an essential role in distributing drugs to pharmacists and hospitals during the pandemic at COVID-19. The use of the IDT (Innovation Diffusion Theory) and TAM (Technology Acceptance Model) models are used because, according to the agreement, TAM is a concept that researchers consider to be the best and suitable for viewing the user's use of IT systems. The study will try to convert these methods with TAM variables, such as Perception of Use, Perception of Ease of Use, Attitude Towards, and Behavior Intentions. Also, IDT variables such as Relative Advantage, Compatibility, Complexity, Trialability, Observability. This study's survey model is the SEM (Structural Equation Model) using a software application. The results showed the pharmaceutical company website could be well received at pharmacists and hospitals in Bandung. The experimental results get a hypothesis, such as finding a significant output. And with the results of this study, getting good results for the people around Bandung.
\end{abstract}

\section{Introduction}

Today the information system is developing rapidly along with the pandemic currently in this world (COVID-19). The development of this information system is compared with hardware technology because computers or other hardware are media that can provide convenience, especially when the pandemic is now [1]-[3].

Every company needs IT [4]-[7] to help with scheduling, purchasing, etc., so that it can be more centralized. In every company other than pharmaceuticals, procurement management must determine the existing goods, especially medicines, and manage inventory in the industry and sales [3], [8].

In its production, pharmaceutical companies in Bandung produce such products as Propepsa, Bevita Suspension, Zemindo, Amiclav, Bionemi, Calnic, D-Vit, Estin, Flamic, Fosicol, Gastrolan, Grafix, Grafed, Imox, Loxil, Mesol, Moretic, etc. , and

\footnotetext{
* Corresponding Author: Mochammad Haldi Widianto, Kecamatan Buah Batu, Bandung, Indonesia, Email: mochamad.widianto@binus.ac.id
}

distributes sales results to all regions in Indonesia. Every sale of medicines to pharmacies and hospitals needs to make orders ordered from each distributor and sub-distributor [9], [10].

According to previous research sources in manufacturing Information Technology (IT) system, products in pharmaceutical companies are still traditional with direct analysis (interviews with PT) combined with the waterfall method [11], [12]. Today researchers use the waterfall method. Barriers that became obstacles were found from the results of interviews using too many typical office applications. So, now the researcher builds some websites to maximize utilization system information in the pharmaceutical company.

Researchers have carried out many web analysis theories, one of which is the Innovation Diffusion Theory (IDT) and the Technology Acceptance Model (TAM) [13], [14]. Explanation TAM is the instrument for anticipating the probability of another innovation being received inside a gathering or an association. 
In light of the hypothesis of contemplated activity, it has by a wide margin been the most broadly talked about among all the connected models. What's more, dictated by two convictions: saw value, which is characterized as the forthcoming client's abstract likelihood that utilizing a particular application framework will build one's work execution inside a hierarchical setting, and saw usability, which alludes to how much the planned client anticipates that the objective framework should be liberated from exertion. IDT is utilized to clarify how groundbreaking thoughts and new practices are spread inside and between associations. It is a cycle of dispersal through arranged systems to empower advancements to be received [15], [16].

With the results of the information system and the use of technology from the pharmaceutical company website in Bandung, it is necessary to measure the extent of the successful implementation. The use of the TAM [17]-[19] and IDT [15], [20], [21] model is based on the fact that so far, TAM is a concept that is considered the best and suitable in explaining user behavior towards information technology systems.

As a comparison with previous research, on [16] using a comparison application with the labor market, while on this application, researchers use pharmaceutical companies to see their effects, it is expected to be useful for the pharmaceutical company in assessing the attachment and improvising the company's IT system.

\section{Theoretical Background}

According to [8], [22], [23] said if the progress of the company can create healthy communities and increased life expectancy, produce and spread drugs, and ultimately lead to the commercialization of the development of drug distribution. Develop is a way to understand other thinking, useful methods, and hope for progress, where development is very rapid, with new ideas and useful. It is IT's use for recent and varied advancements as well as increasing or lower-cost nature, to meet or exceed our own goal

Innovation [24]-[26] is the essential stage of the diffusion processor so that it can trigger the process to continue rapidly. Meanwhile, good communication refers to a channel used to transfer information from one party to another so that it can start the same thoughts. The following is an illustration of diffusion theory or IDT as shown in Figure 1.

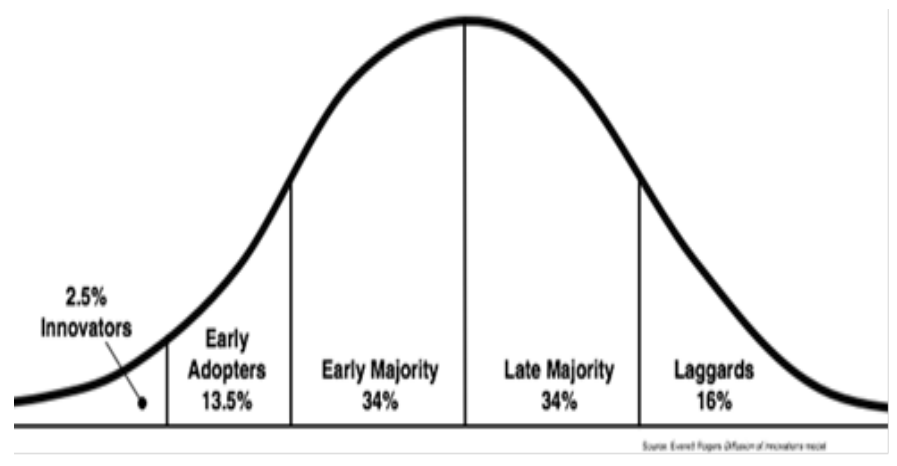

Figure 1: Innovation Diffusion Theory

Furthermore, the theory put forward [16], [27], [28] has a significant meaning and has conflicts in leadership management.
A temporary conclusion can be drawn, among other things, describing the principles that influence the rate of development deprivation, such as the progress phase, so that a leadership process is needed. Regulations affecting the deployment stage of development include the quality of the product (view progress), the type of development choice, the correspondence channel (correspondence channel), the conditions of the social framework, and the specialist work progress (change operator). The characteristics of IDT, according to [8], [9] as follow:

Rogers (1983) suggests five characteristics innovations include:

1) relative advantage,

2) compatibility,

3) complexity,

4) ability to be tested (trialability) and

5) observability.

In contrast to IDT, TAM is a new derivative that was introduced by Davis in 1986. The goals of TAM are more generalized to explain the behavior of the primary user of the computer. TAM uses the TRA derivative as a theoretical basis for deriving a causal relationship between two fundamental beliefs, such as Perceived Usefulness and Perceived Ease of Use [18], [19]. More evident than TRA because TAM is used unusually for the use of innovations in computerized techniques. This TAM model is ready to predict something and can clearly explain to experts and professionals to find out why a factor is not known and provide the potential for progress that has the right accuracy.

Using the TAM factor is to provide initial advancement of the effects of external factors on inner beliefs, frame of mind, and goals. Achieve this goal by distinguishing some of the fundamental elements put forward in the investigation following the principles that influence psychological factors and feelings of recognition in computer engineering and using TRA as a possible reason for severing the relationship of the research factor model. The stamp positions two beliefs, particularly seeing perceived convenience and benefits as essential elements of PC recognition behavior, as seen in Figure 3.

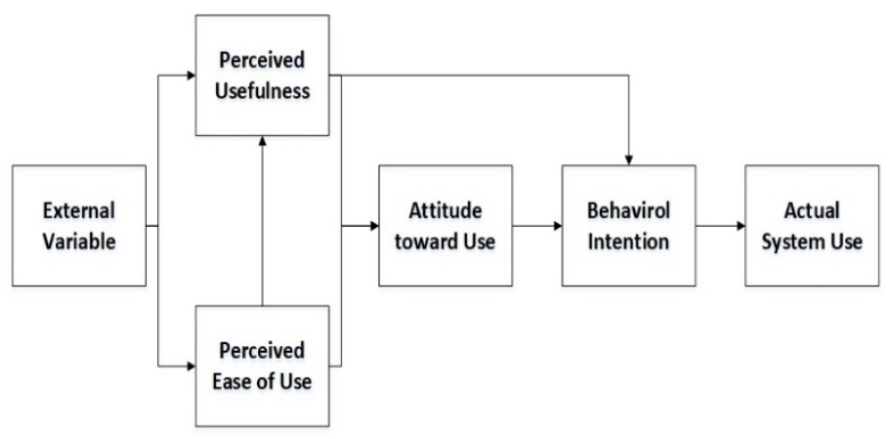

Figure 2: Technology Acceptance Model (TAM)

Based on the literature's systematic review, different works have been found that strengthen the areas of knowledge processing and representation. The branch that is responsible for the processes of knowledge representation in Artificial Intelligence, to achieve this, it is necessary to group situations that 
have similar characteristics or properties instead of making individual representations.

\section{System Analysis}

\subsection{Business Process}

The pharmaceutical [29]-[32] business process is indeed very complicated, which can be interpreted as having a set of activities or jobs that are structured and interrelated. It is used to solve a problem or produce a new pharmaceutical product. Several sections are used to analyze employees' work procedures in IT to see the finished drug supplies at a pharmaceutical manufacturing plant in Bandung, and this business process aims to identify and problems that occur and expected needs.

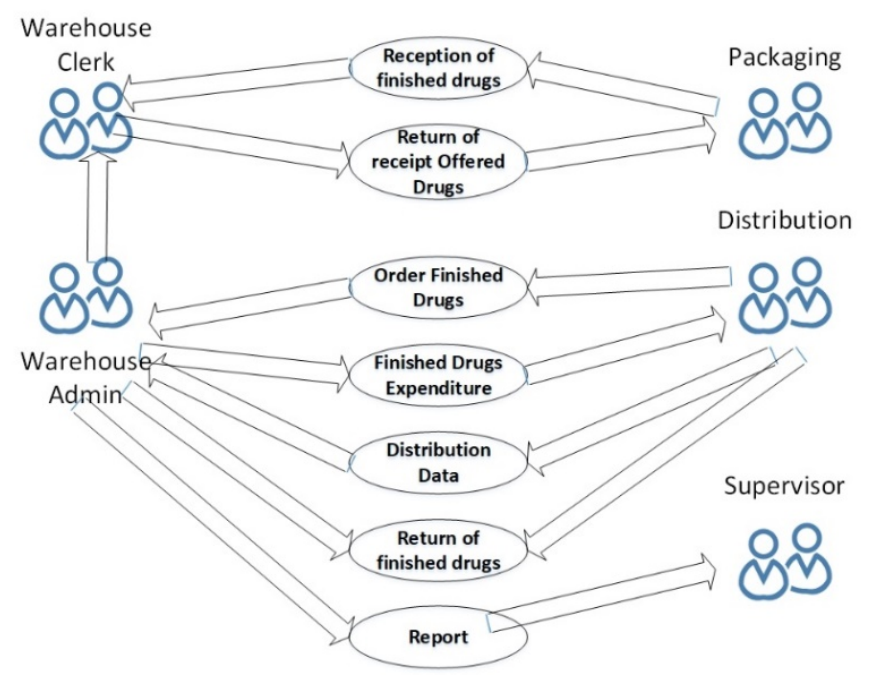

Figure 3: Business Object of Drug Inventory

Table 1: Information Needs

\begin{tabular}{|c|c|c|c|}
\hline No & Name & Goals & Frequency \\
\hline 1 & $\begin{array}{l}\text { Drug Receipt } \\
\text { Report }\end{array}$ & $\begin{array}{l}\text { Warehouse } \\
\text { Supervisor }\end{array}$ & Monthly Period \\
\hline 2 & $\begin{array}{c}\text { Report on Drug } \\
\text { Expenditures }\end{array}$ & $\begin{array}{l}\text { Warehouse } \\
\text { Supervisor }\end{array}$ & Monthly Period \\
\hline 3 & $\begin{array}{c}\text { Distributor Data } \\
\text { Report }\end{array}$ & $\begin{array}{l}\text { Warehouse } \\
\text { Supervisor }\end{array}$ & Supervisor Needs \\
\hline 4 & $\begin{array}{c}\text { GOJ Inventory } \\
\text { Report }\end{array}$ & $\begin{array}{l}\text { Warehouse } \\
\text { Supervisor }\end{array}$ & Monthly Period \\
\hline 6 & Delivery orders & Distributor & Every Day \\
\hline 7 & $\begin{array}{c}\text { Proof of receipt } \\
\text { of finished } \\
\text { pharmaceutical }\end{array}$ & $\begin{array}{l}\text { Warehouse } \\
\text { Admin }\end{array}$ & Every Day \\
\hline 8 & $\begin{array}{c}\text { Reports on } \\
\text { Receiving } \\
\text { Medication for } \\
\text { Finished } \\
\text { Medicines }\end{array}$ & $\begin{array}{l}\text { Warehouse } \\
\text { Supervisor }\end{array}$ & Supervisor Needs \\
\hline 9 & $\begin{array}{c}\text { Report on Drug } \\
\text { Expenditures } \\
\text { Return }\end{array}$ & $\begin{array}{l}\text { Warehouse } \\
\text { Supervisor }\end{array}$ & Supervisor Needs \\
\hline
\end{tabular}

www.astesj.com

\subsection{Identification of User Needs}

The information system [33]-[35] must provide the consumer for comfort and classification incompatible with the requirements, though these system conditions are as measures:

1. The working framework will have to make the user's job easier

2. The framework produced must have data protection so that its use can be restricted

3. Employees who have been enrolled must use the program

4. The system made must be capable of displaying reports and even printing reports according to existing data input

5. All information should be available and often easy to find and obtain to help achieve the use of this system by users

6. This information system needs to be able to create its use straightforward for the warehouseman.

7. The phone designed must be able to initiate the input and distribution of pharmaceutical completes.

What needs are described in table 1:

\subsection{Program Testing}

The system must be free from errors before the process is implemented. To that end, the program has to be tested in advance to investigate the potential errors. This system is evaluated or reviewed using the White Box and Black Box techniques. Black Box Testing where for testing the program immediately looks at the application without knowing the program's structure. This test is carried out to see whether a program has met or not [8], [24], [36].

\section{4. $\quad$ Result}

The first few contents contain the Logo etc. Next includes some vital information about the company. The most important thing is the log-in section. Employees can't enter this website.

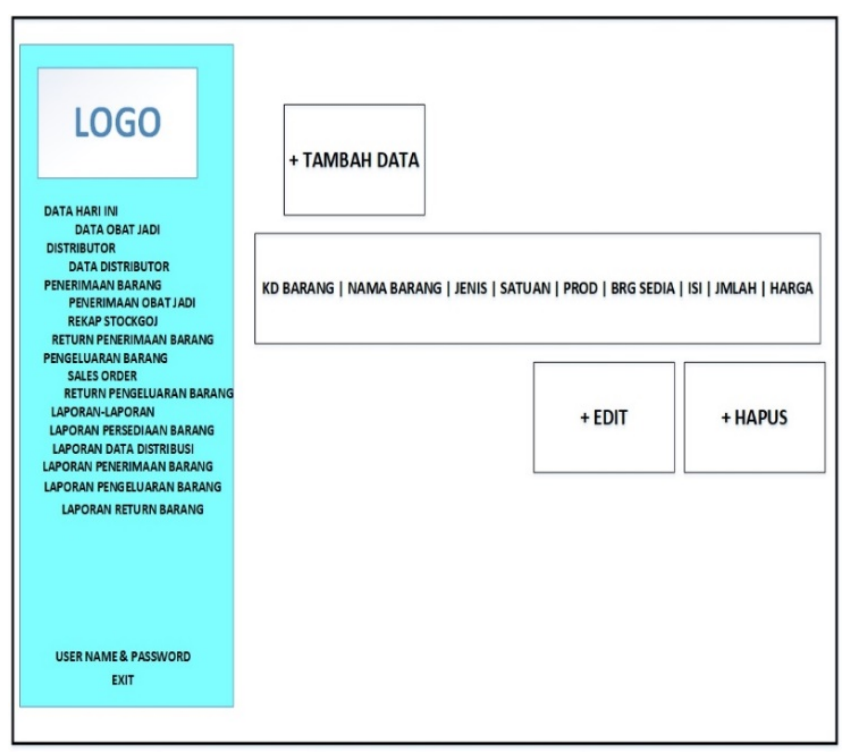

Figure 4: Login Interface Home Admin

Furthermore, the same as before carried out several tests using the black box, with the results as in the following table: 
Table 2: BlackBox Test Home Admin

\begin{tabular}{|l|l|l|}
\hline Component testing & Expected results & Result \\
\hline Add Data & May add data & Successful \\
\hline Connect Distributor & $\begin{array}{l}\text { Can Connect } \\
\text { Distributor }\end{array}$ & Successful \\
\hline Received Goods & $\begin{array}{l}\text { Can Connect } \\
\text { received goods }\end{array}$ & Successful \\
\hline Report Distribution & $\begin{array}{l}\text { Can Connect } \\
\text { Report } \\
\text { Distribution }\end{array}$ & Successful \\
\hline Log Out & Can Logout & Successful \\
\hline
\end{tabular}

Of all the tests carried out by BlackBox and according to [37], the method of using waterfall is still efficient and effective for use in making websites for pharmaceutical companies.

\subsection{Testing the Overall Research Model}

This model [38], [39] shows that the model consists of 9 constructs, namely: RA (Relative Advantage), CPA (Compatibility), CPL (Complexity), TRI (Trialability), OB (Observability), PU (Perceived Usefulness), PEU (Perceived Ease of Use), AT (Attitude Towards), BI (Behavioral Intention). In this model, the relationships between constructs and the interrelationships between indicators are adjusted to the research hypothesis. The overall model test results using SPSS AMOS 22 produce the level of conformity, as shown in the table.

\subsection{Hypothesis Testing with SEM}

This test is done to see the relationship between the constructs that exist in the research model. The basis for decision-making was taken by looking at the regression weights for the constructs related to the test results using SPSS AMOS version 22. If $\mathrm{p}>0.05$, then $\mathrm{H} 1$ is rejected, and if $\mathrm{p}<0.05$ or denoted by $* * *$, then $\mathrm{H} 1$ is accepted as described in table 6 .

Table 3: Modification Structural Model Suitability Test Results

\begin{tabular}{|l|l|l|l|}
\hline Model Fit & Result & Acceptable Level & Interpretation \\
\hline CMIN (Chi Square) & 1817.325 & $\begin{array}{l}\text { Beetween Saturated and } \\
\text { Independence Model }\end{array}$ & Good Conformity \\
\hline $\begin{array}{l}\text { GFI (Goodness of Fit } \\
\text { Index) }\end{array}$ & 0.747 & 0 (tidak fit) s/d 1 (Fit) & Good Conformity \\
\hline $\begin{array}{l}\text { AGFI (Adjusted GFI) } \\
\text { RSMEA (Root mean } \\
\text { square } \\
\text { approximation) }\end{array}$ & 0.715 & 0 (tidak fit) s/d 1 (Fit) & Good Conformity \\
\hline $\begin{array}{l}\text { TLI (Tucker-Lewis } \\
\text { Index) }\end{array}$ & 0.833 & $<0.080$ & Good Conformity \\
\hline $\begin{array}{l}\text { NFI (Normed Fit } \\
\text { Index) }\end{array}$ & 0.741 & 0 (tidak fit) s/d 1 (Fit) & Good Conformity \\
\hline $\begin{array}{l}\text { CFI (Confirmatory Fit } \\
\text { Index) }\end{array}$ & 0.845 & 0 (tidak fit) s/d 1 (Fit) & Good Conformity \\
\hline $\begin{array}{l}\text { PNFI (Parcimonious } \\
\text { Fit Index) }\end{array}$ & 0.687 & Good Conformity & Good Conformity \\
\hline
\end{tabular}

Source: SPSS AMOS 22

Table 4: Value of Regression Weight Modified Research Model

\begin{tabular}{|l|l|l|l|l|l|l|l|l|}
\hline \multicolumn{2}{|l|}{} & Estimate & S.E. & C.R. & P & Label & Result \\
\hline PEU & $<---$ & RA & -2.936 & 8.671 & -.339 & .357 & par_37 & Insignificant \\
\hline PEU & $<---$ & CPA & 3.203 & 8.715 & .367 & .137 & par_39 & Insignificant \\
\hline
\end{tabular}




\begin{tabular}{|c|c|c|c|c|c|c|c|c|}
\hline & & & Estimate & S.E. & C.R. & $\mathbf{P}$ & Label & Result \\
\hline PEU & $<--$ & CPL & .133 & 2.315 & .057 & .459 & par_41 & Insignificant \\
\hline PEU & $<---$ & OB & -.010 & .324 & -.032 & .047 & par_43 & Significant \\
\hline PEU & $<---$ & TRI & .495 & .789 & .627 & .035 & par_50 & Significant \\
\hline PU & $<---$ & RA & .160 & 1.551 & .103 & .189 & par 36 & Insignificant \\
\hline $\mathrm{PU}$ & $<---$ & CPA & .043 & 1.486 & .029 & .397 & par_38 & Insignificant \\
\hline $\mathrm{PU}$ & $<---$ & CPL & -.33 & .668 & -.528 & .035 & par_40 & Significant \\
\hline $\mathrm{PU}$ & $<--$ & OB & .706 & .130 & 5.422 & $* * *$ & par_42 & Significant \\
\hline PU & $<---$ & PEU & .063 & .291 & .215 & .038 & par_44 & Significant \\
\hline $\mathrm{PU}$ & $<---$ & TRI & -.036 & .118 & -.303 & .267 & par_49 & Insignificant \\
\hline AT & $<---$ & $\mathrm{PU}$ & -.061 & .038 & -1.618 &.$* * *$ & par_45 & Significant \\
\hline AT & $<---$ & PEU & .941 & .074 & 12.647 & *** & par_47 & Significant \\
\hline BI & $<---$ & PU & .010 & .044 & .216 & .298 & par_46 & Insignificant \\
\hline $\mathrm{BI}$ & $<---$ & AT & .966 & .080 & 12.033 & $* * *$ & par_48 & Significant \\
\hline
\end{tabular}

Table 5: Summary of Research Hypothesis Testing Results

\begin{tabular}{|c|c|c|c|}
\hline NO & Hypothesis $\left(\mathrm{H}_{1}\right)$ & $\mathbf{P}$ & Noted \\
\hline 1 & $\begin{array}{l}\text { There is a significant relationship between } \\
\text { Perceived Ease of Use with Relative Advantage }\end{array}$ & .357 & $\mathrm{H}_{1}$ Rejected \\
\hline 2 & $\begin{array}{l}\text { There is a significant relationship between } \\
\text { Perceived Ease of Use with Persepsi Compatibility }\end{array}$ & .137 & $\mathrm{H}_{1}$ Rejected \\
\hline 3 & $\begin{array}{l}\text { There is a significant relationship between } \\
\text { Perceived Ease of Use with Complexity }\end{array}$ & .459 & $\mathrm{H}_{1}$ Rejected \\
\hline 4 & $\begin{array}{l}\text { There is a significant relationship between } \\
\text { Perceived Ease of Use with Observability }\end{array}$ & .047 & $\mathrm{H}_{1}$ Accepted \\
\hline 5 & $\begin{array}{l}\text { There is a significant relationship between } \\
\text { Perceived Ease of Use with Trialability }\end{array}$ & .035 & $\mathrm{H}_{1}$ Accepted \\
\hline 6 & $\begin{array}{l}\text { There is a significant relationship between } \\
\text { Perceived Usefulness with Relative Advantage }\end{array}$ & .189 & $\mathrm{H}_{1}$ Rejected \\
\hline 7 & $\begin{array}{l}\text { There is a significant relationship between } \\
\text { Perceived Usefulness with Compatibility }\end{array}$ & .397 & $\mathrm{H}_{1}$ Rejected \\
\hline 8 & $\begin{array}{l}\text { There is a significant relationship between } \\
\text { Perceived Usefulness with Complexity }\end{array}$ & .035 & $\mathrm{H}_{1}$ Accepted \\
\hline 9 & $\begin{array}{l}\text { There is a significant relationship between } \\
\text { Perceived Usefulness with Observability }\end{array}$ & $* * *$ & $\mathrm{H}_{1}$ Accepted \\
\hline
\end{tabular}


M.H. Widianto / Advances in Science, Technology and Engineering Systems Journal Vol. 6, No. 1, 464-471 (2021)

\begin{tabular}{|c|c|c|c|}
\hline NO & Hypothesis $\left(\mathrm{H}_{1}\right)$ & $\mathbf{P}$ & Noted \\
\hline 10 & $\begin{array}{l}\text { There is a significant relationship between } \\
\text { Perceived Usefulness with Perceived Ease of Use }\end{array}$ & .038 & $\mathrm{H}_{1}$ Accepted \\
\hline 11 & $\begin{array}{l}\text { There is a significant relationship between } \\
\text { Perceived Usefulness with Trialability }\end{array}$ & .267 & $\mathrm{H}_{1}$ Rejected \\
\hline 12 & $\begin{array}{l}\text { There is a significant relationship between Attitude } \\
\text { Towards with Perceived Usefulness }\end{array}$ & $* * *$ & $\mathrm{H}_{1}$ Accepted \\
\hline 13 & $\begin{array}{l}\text { There is a significant relationship between Attitude } \\
\text { Towards with Perceived Ease of Use }\end{array}$ & $* * *$ & $\mathrm{H}_{1}$ Accepted \\
\hline 14 & $\begin{array}{l}\text { There is a significant relationship between } \\
\text { Behavioral Intention for Perceived Usefulness }\end{array}$ & .298 & $\mathrm{H}_{1}$ Rejected \\
\hline 15 & $\begin{array}{l}\text { There is a significant relationship between } \\
\text { Behavioral Intention with Attitude Towards }\end{array}$ & $* * *$ & $\mathrm{H}_{1}$ Accepted \\
\hline
\end{tabular}

Table 6: Re-Test Results of Conformity of Modified Structural Models

\begin{tabular}{|l|l|l|l|}
\hline Model Fit & Result & Acceptable Level & Interpretation \\
\hline CMIN (Chi Square) & 1279.601 & $\begin{array}{l}\text { Between Saturated and } \\
\text { Independence Model }\end{array}$ & Good \\
\hline GFI (Goodness of Fit Index) & 0.772 & 0 (unfit) s/d 1 (Fit) & Good \\
\hline AGFI (Adjusted GFI) & 0.738 & 0 (unfit) s/d 1 (Fit) & Good \\
\hline $\begin{array}{l}\text { RSMEA (Root mean square error } \\
\text { TLI (Tucker-Lewis Index) }\end{array}$ & 0.074 & $<0.080$ & Good \\
\hline $\begin{array}{l}\text { NFI (Normed Fit Index) } \\
\text { CFI (Confirmatory Fit Index) }\end{array}$ & 0.831 & 0 (unfit) s/d 1 (Fit) & Good \\
\hline PNFI (Parcimonious Fit Index) & 0.699 & 0 (unfit) s/d 1 (Fit) & Good \\
\hline
\end{tabular}

Table 7: Re-Test Results of Conformity of Modified Structural Models

\begin{tabular}{|c|c|c|c|}
\hline NO & Hypothesis $\left(\mathrm{H}_{1}\right)$ & $\mathbf{P}$ & Notes \\
\hline 1 & $\begin{array}{l}\text { There is a significant relationship between Perceived Ease } \\
\text { of Use with Observability }\end{array}$ & $* * *$ & $\mathrm{H}_{1}$ Accepted \\
\hline 2 & $\begin{array}{l}\text { There is a significant relationship between Perceived Ease } \\
\text { of Use with Trialability }\end{array}$ & .040 & $\mathrm{H}_{1}$ Accepted \\
\hline 3 & $\begin{array}{l}\text { There is a significant relationship between Perceived } \\
\text { Usefulness with Observability }\end{array}$ & $* * *$ & $\mathrm{H}_{1}$ Accepted \\
\hline 4 & $\begin{array}{l}\text { There is a significant relationship between Perceived } \\
\text { Usefulness with Perceived Ease of Use }\end{array}$ & $* * *$ & $\mathrm{H}_{1}$ Accepted \\
\hline
\end{tabular}


M.H. Widianto / Advances in Science, Technology and Engineering Systems Journal Vol. 6, No. 1, 464-471 (2021)

\begin{tabular}{|l|l|l|l|}
\hline NO & Hypothesis $\left.\mathbf{( H}_{\mathbf{1}}\right)$ & $\mathbf{P}$ & Notes \\
\hline 5 & $\begin{array}{l}\text { There is a significant relationship between Perceived } \\
\text { Usefulness with Complexity }\end{array}$ & .029 & $\mathrm{H}_{1}$ Accepted \\
\hline 6 & $\begin{array}{l}\text { There is a significant relationship between Attitude } \\
\text { Towards with Perceived Usefulness }\end{array}$ & .019 & $\mathrm{H}_{1}$ Accepted \\
\hline 7 & $\begin{array}{l}\text { There is a significant relationship between } \text { Attitude } \\
\text { Towards with Perceived Ease of Use }\end{array}$ & $* * *$ & $\mathrm{H}_{1}$ Accepted \\
\hline 8 & $\begin{array}{l}\text { There is a significant relationship between Behavioral } \\
\text { Intention with Attitude Towards }\end{array}$ & $* * *$ & $\mathrm{H}_{1}$ Accepted \\
\hline
\end{tabular}

Among them are the Relative Advantage hypothesis with Perceived Usefulness and Perceived Ease of Use. It is apart from the use of the pharmaceutical company, which provides opportunities for education graduates and students to apply for jobs to companies that have collaborated. The presence of this pharmaceutical company indeed feels various benefits and aspects of benefits. However, the company still determines the work that is obtained or the opportunity to receive job applicants.

Graduates and students also do not feel the influence of compatibility with the aspects of benefits and convenience. This happens as the development of information technology that makes accessing the internet through various media makes the pharmaceutical company system less suitable because it cannot reach the mobile side.

The pharmaceutical company's complexity was felt not to affect the aspect of ease, and trialability did not change the character of benefits. Because the pharmaceutical company is only intended for the academic community, the wider community can only access it. And also does not feel the effect of benefits on the intention to use, the tendency of job applicants triggers it will stop looking for another job if the person has found a job by expectations.

\section{Conclusion}

Based on the results of research conducted on the implementation of the pharmaceutical company using. The use of the IDT and TAM models approaches processed using the SPSS AMOS 22 application. The following conclusions can be obtained, and Relative Advantage does not affect Perceived Usefulness in the pharmaceutical company's application. Relative Advantage does not affect the Perceived Ease of Use in the application of the pharmaceutical company. Compatibility does not affect the Perceived Usefulness in the application of the pharmaceutical company

\section{References}

[1] N. Komalasari, JOURNAL Budiman, and E. Fernando, "Effect of Education, Performance, Position and Information Technology Competency of Information Systems to Performance of Information System," 2018 International Seminar.. Res. Inf. Technol. Intell. Syst., 221-226, 2016.

[2] M. Kejriwal, "Information Extraction," SpringerBriefs Comput. Sci., 9-31, 2019.

[3] W. Sardjono and T. L. Wijaya, "Evaluation of Budgeting Management Information System at DKI Jakarta Forestry Service," Proc. 2018
International Conference Inf. Manag. Technol. ICIMTech, 33-37, 2018.

[4] P. A. W. Putro and R. Rionaldy, "Implementation of the Park Schema on User Authentication Services Using Password-Based Web Codeigniter Library to Overcome Man in the Middle Attack," Proc. 2019 4th International Conference Informatics Comput. ICIC-2019, 1-5, 2019.

[5] L. Climate, "Characteristics of Highly Effective Social Studies Teaching and Learning in KY" GEMA Online ${ }^{\circledR}$ Journal of Language Studies, 12(1), 2012.doi: 10.1080/0218879020220205\#preview

[6] L. Goswami, M. K. Kaushik, R. Sikka, V. Anand, K. Prasad Sharma, and M. Singh Solanki, "IOT Based Fault Detection of Underground Cables through Node MCU Module," 2020 International Conference Comput. Sci. Eng. Appl. ICCSEA2020, 1-6, 2020.

[7] O. Lopez et al., "White Paper on Critical and Massive Machine Type Communication Towards 6G," arXiv preprint arXiv:2004.14146, 2020.

[8] A. Darisman and M. H. Widianto, "Design and Development of Pharmaceutical Company Information System Based on Website using the Waterfall Model," International Journal Recent Technol. Eng., 8(4), 39893993, 2019.

[9] U. C. Bandara and T. S. M. Amarasena, "Impact of Relative Advantage, Perceived Behavioural Control and Perceived Ease of Use on Intention to Adopt with Solar Energy Technology in Sri Lanka," Proc. Conference Ind. Commer. Use Energy, ICUE, 1-9, 2019.

[10] N. Ellahi, Z. Maroof, H. Z. Mehmood, and A. Kiani, "Education and Socioeconomic Development: Finding the Way Forward.," Science International, 29(2), 361-366, 2017.

[11] A. I. Graell Amat and G. Liva, "Finite-length analysis of irregular repetition slotted ALOHA in the waterfall region," IEEE Commun. Lett., 22(5), 886889, 2018. DOI: 10.1109/LCOMM.2018.2812845

[12] I. A. Puspita, R. P. Soesanto, and F. Muhammad, "Designing Mobile Geographic Information System for Disaster Management by Utilizing Wisdom of the Crowd," 2019 IEEE 6th International Conference Ind. Eng. Appl. ICIEA 2019, 496-500, 2019.

[13] N. Aeni Hidayah, N. Hasanati, R. Novela Putri, K. Fiqry Musa, Z. Nihayah, and A. Muin, "Analysis Using the Technology Acceptance Model (TAM) and DeLone McLean Information System (DM IS) Success Model of AIS Mobile User Acceptance," 2020 8th International Conference Cyber IT Serv. Manag. CITSM 2020, 2020.

[14] Y. Harb and S. Alhayajneh, "Intention to use BI tools: Integrating technology acceptance model (TAM) and personality trait model," 2019 IEEE Jordan International Conference Electr. Eng. Inf. Technol. JEEIT 2019 - Proc., 494-497, 2019.

[15] W. M. Al-Rahmi et al., "Integrating Technology Acceptance Model with Innovation Diffusion Theory: An Empirical Investigation on Students' Intention to Use E-Learning Systems," IEEE Access, 7, 26797-26809, 2019. DOI: 10.1109/Access.2019.2812845

[16] H. Zhao and Q. Liu, "The practice and research on the promotion mode of MOOCs in higher education based on the innovation diffusion theory," Proc. - 2018 7th International Conference Educ. Innov. through Technol. EITT 2018, 198-203, 2018.

[17] K. Thongkoo, K. Daungcharone, and J. Thanyaphongphat, "Students' Acceptance of Digital Learning Tools in Programming Education Course using Technology Acceptance Model," 2020 International Conference Digit. Arts, Media Technol. with ECTI North. Sect. Conference Electr. Electron. Comput. Telecommun. Eng. ECTI DAMT NCON 2020, 377-380, 2020.

[18] Inayatulloh, "Technology acceptance model (TAM) for the implementation 
of knowledge acquired model for SME," Proc. 2020 International Conference Inf. Manag. Technol, 767-770, 2020.

[19] W. Ike Wahyuning, M. Lubis, W. Witjaksono, and A. H. Azizah, "Implementation of Enterprise Resource Planning (ERP) using Integrated Model of Extended Technology Acceptance Model (TAM) 2: Case Study of PT. Toyota Astra Motor," 2019 7th International Conference Cyber IT Serv. Manag, 1-5, 2019.

[20] T. Cam and T. Tran, "Adding Innovation Diffusion Theory to Technology Acceptance Model: Understanding Consumers' Intention to Use Biofuels in Viet Nam MAN SHIN CHENG," International review of management and business research, 6(2), 595-609, 2017.

[21] M. H. Widianto, "Analysis of application of online work exchange using technology acceptance model and innovation diffusion theory," Journal Theor. Appl. Inf. Technol., 98(10), 1697-1711, 2020.

[22] A. M. Kolesnikov, T. A. Kokodey, T. I. Lomachenko, and Y. I. Mikhailov, "Modeling the Optimal Format of Strategic Management of a Company for Establishing a Region's Sustainable Development," Proc. 2018 International Conference ' 'Quality Manag. Transp. Inf. Secur. Inf. Technol. IT QM IS 2018, 848-850, 2018.

[23] H. Fan, "Theoretical basis and system establishment of China food safety intelligent supervision in the perspective of internet of things," IEEE Access, 7, 71686-71695, 2019. DOI: 10.1109/ACCESS.2019.2919582

[24] M. H. Widianto, Ranny, N. F. Thejowahyono, and S. B. Handoyo, "Internet of things based on smart mirror to improve interactive learning," International JOURNAL Emerg. Trends Eng. Res., 8(9), 4900-4907, 2020.

[25] H. Zhang, H. Ye, L. Zhang, and L. Li, "Base on the design and implementation of the quality control system of food antioxidant vitamins c," Proc. - 2020 3rd International Conference Adv. Electron. Mater. Comput. Softw. Eng. AEMCSE 2020, 31-34, 2020.

[26] J. Wang, C. Jiang, H. Zhang, Y. Ren, K.-C. Chen, and L. Hanzo, "Thirty Years of Machine Learning: The Road to Pareto-Optimal Wireless Networks," IEEE Commun. Surv. Tutorials, 22(3), 1472-1514, 2020.

[27] A. Solomon and R. Steyn, "Leadership style and leadership effectiveness: Does cultural intelligence moderate the relationship?," Acta Commer., 17(1), 1-13, 2017. doi: 10.1111/j.1540-4560.2011.01730.x

[28] A. Nimota, JOURNAL Kadir, T. A. Adebayo, and S. Abayomi, "Visionary Leadership and Staff Innovative Behaviour in Public Colleges of Education In Kwara State, Nigeria," International JOURNAL Educ., 12(2), 72, 2020.

[29] F. Guerriero, R. Guido, G. Mirabelli, and V. Solina, "Supporting a Pharmaceutical Wholesaler in the Vehicle Fleet Organization: An Italian Case Study," Proc. 2019 10th IEEE International Conference Intell. Data Acquis. Adv. Comput. Syst. Technol. Appl. IDAACS 2019, 2, 765-768, 2019.

[30] L. Wang and Z. Huang, "Research on the Synergetic Innovation between Pharmaceutical Enterprises and Scientific Research Institutions Based on the Quantum Game," IEEE Access, 8, 63718-63724, 2020. DOI: 10.1109/ACCESS.2020.2976544

[31] X. Jiang, M. Wang, Z. Tian, Y. Lu, and K. Chen, "Evaluation Method of Storage Assignment for Intelligent Pharmaceutical Warehouse," 2019 IEEE Eurasia Conference IOT, Commun. Eng. ECICE 2019, 434-437, 2019.

[32] W. Yang and H. Wang, "Application of electrical capacitance tomography in pharmaceutical manufacturing processes," I2MTC 2019 - 2019 IEEE International Instrum. Meas. Technol. Conference Proc., 2019-May, 1-6, 2019.

[33] Y. Chen, B. M. Howe, and C. Yang, "Actively Controllable Switching for Tree Topology Seafloor Observation Networks," IEEE JOURNAL Ocean. Eng., 40(4), 993-1002, 2015. DOI: 10.1109/JOE.2014.2362830

[34] L. Xing, K. Deng, H. Wu, P. Xie, H. V. Zhao, and F. Gao, "A Survey of across Social Networks User Identification," IEEE Access, 7, 137472 137488, 2019.

[35] S. Gu, F. Yuan, H. Wu, H. Shao, and L. Cheng, "A Novel Two-Stage Framework for User Identification Across Social Networks," 2019 2nd International Conference Artif. Intell. Big Data, ICAIBD 2019, 266-270, 2019.

[36] S. Adhy, A. Prasetio, B. Noranita, and R. Saputra, "Usability Testing of Weather Monitoring on Android Application," 2018 2nd International Conference Informatics Comput. Sci. ICICoS 2018, 81-86, 2019.

[37] K. I. Satoto, K. T. Martono, R. R. Isnanto, and R. Kridalukmana, "Design of management information systems research, publications and community service," ICITACEE 2015 - 2nd International Conference Inf. Technol. Comput. Electr. Eng. Green Technol. Strength. Inf. Technol. Electr. Comput. Eng. Implementation, Proc., 117-122, 2016.

[38] J. Wu et al., "Structural Uncertainty," Ecological Modelling, 204(3-4), 289300. https://doi.org/10.1016/j.ecolmodel.2007.01.004

[39] F. Liu et al., "SAR Image Segmentation Based on Hierarchical Visual

www.astesj.com
Semantic and Adaptive Neighborhood Multinomial Latent Model," IEEE Trans. Geosci. Remote Sens., 54(7), 4287-4301, 2016. DOI: 10.1109/TGRS.2016.2539155 